\title{
Chiral Amino and Imino-Alcohols Based on $(R)$-Limonene
}

\author{
Rodrigo S. Fuscaldo, ${ }^{a}$ Eduam O. Boeira, ${ }^{a}$ Rafael Stieler, ${ }^{a}$ Diogo S. Lüdtke ${ }^{a}$ \\ and José R. Gregório ${ }^{\circledR} * a$
}

${ }^{a}$ Instituto de Química, Universidade Federal do Rio Grande do Sul, 91501-970 Porto Alegre-RS, Brazil

\begin{abstract}
Derivatives of the natural occurring and inexpensive terpene $(R)$-limonene were synthetized and completely characterized. Starting from internal olefin epoxidation, followed by epoxide opening with sodium azide and azide reduction with $\mathrm{LiAlH}_{4}$, two chiral amino-alcohols were obtained. The amino-alcohols were reacted with three different aldehydes, generating six new imino-alcohols, two of them yielding crystals suitable for X-ray diffraction characterization. The reduction of four of these compounds with $\mathrm{LiAlH}_{4}$ led to new amino-alcohols. All derivatives were obtained with good overall yields through simple reaction protocols.
\end{abstract}

Keywords: natural products, $N, O$ ligands, Schiff bases, sustainable chemistry, renewable sources

\section{Introduction}

Natural asymmetric molecules are excellent starting points for the synthesis of chiral compounds since they are usually enantiomerically pure, obtained from renewable sources and, for most of them, inexpensive. Terpenes are great natural asymmetric building blocks: mainly produced by a variety of plants, some exemplars can be transformed into more complex compounds with high aggregated value, used as ligands or catalyst for asymmetric reactions, for instance. ${ }^{1}$ One good example of this type of compound is $(R)$-limonene (Scheme 1), which is present in high quantities on citric fruits, especially in orange peel. Since Brazil is the world top producer of orange and its juice (having the peel as a side product), ${ }^{2}$ it is economically interesting to give $(R)$-limonene nobler applications compared to solvent for paint, additive to food, hygiene products or cosmetics and other classical uses of this terpene. ${ }^{3}$

$(R)$-Limonene has two chemically distinct double bonds that make possible a large number of chemical modifications in order to synthesize more complex molecules ${ }^{4-6}$ with applications spread over medicinal chemistry, ${ }^{7-13}$ total synthesis of natural products, ${ }^{14-18}$ and others, including applications in catalysis. The first use of limonenederived chiral ligands in catalytic systems was published by Lahuerta $e t a l .{ }^{19}$ in 2000 , where the researchers used

*e-mail: jrg@ufrgs.br
$\mathrm{LiPPh}_{3}$ to perform previously reported selective epoxide opening in limonene oxides,,$^{20}$ generating phosphinealcohols that induced low selectivity in Rh-catalyzed $\mathrm{C}-\mathrm{H}$ insertion and cyclopropanation reactions. Since then, there was a narrow development in the ligand synthesis starting from limonene, having excellent results in terms of yield and stereoselectivity, however distributed into two main reactions: organozinc additions ${ }^{21-25}$ and ruthenium catalyzed asymmetric hydrogen transfer reactions. ${ }^{26-28}$ Usually, its internal cis and trans-oxides are used as substract for selective epoxide opening with amines in order to produce secondary or tertiary chiral amino-alcohols, although there are some divergent methodologies using amino-oximes ${ }^{26,29,30}$ or aziridines. ${ }^{28}$

In order to increase structure variety, hoping this would widen the application of limonene-based chiral molecules, we present herein the synthesis of new amino- and iminoalcohols based on $(R)$-limonene through simple and high yielding reactions as epoxidation, epoxide opening, azide reduction, imine formation and reduction (Scheme 1).

\section{Results and Discussion}

In order to produce $(R)$-limonene based imines, it was necessary to synthesize its primary amines. We performed the epoxidation of the internal double bond using $\mathrm{H}_{2} \mathrm{O}_{2}$ as oxidant and methyltrioxorhenium $\left(\mathrm{MeReO}_{3}, \mathrm{MTO}\right)$ as catalyst, as described by Rudler et al. ${ }^{31}$ producing a 


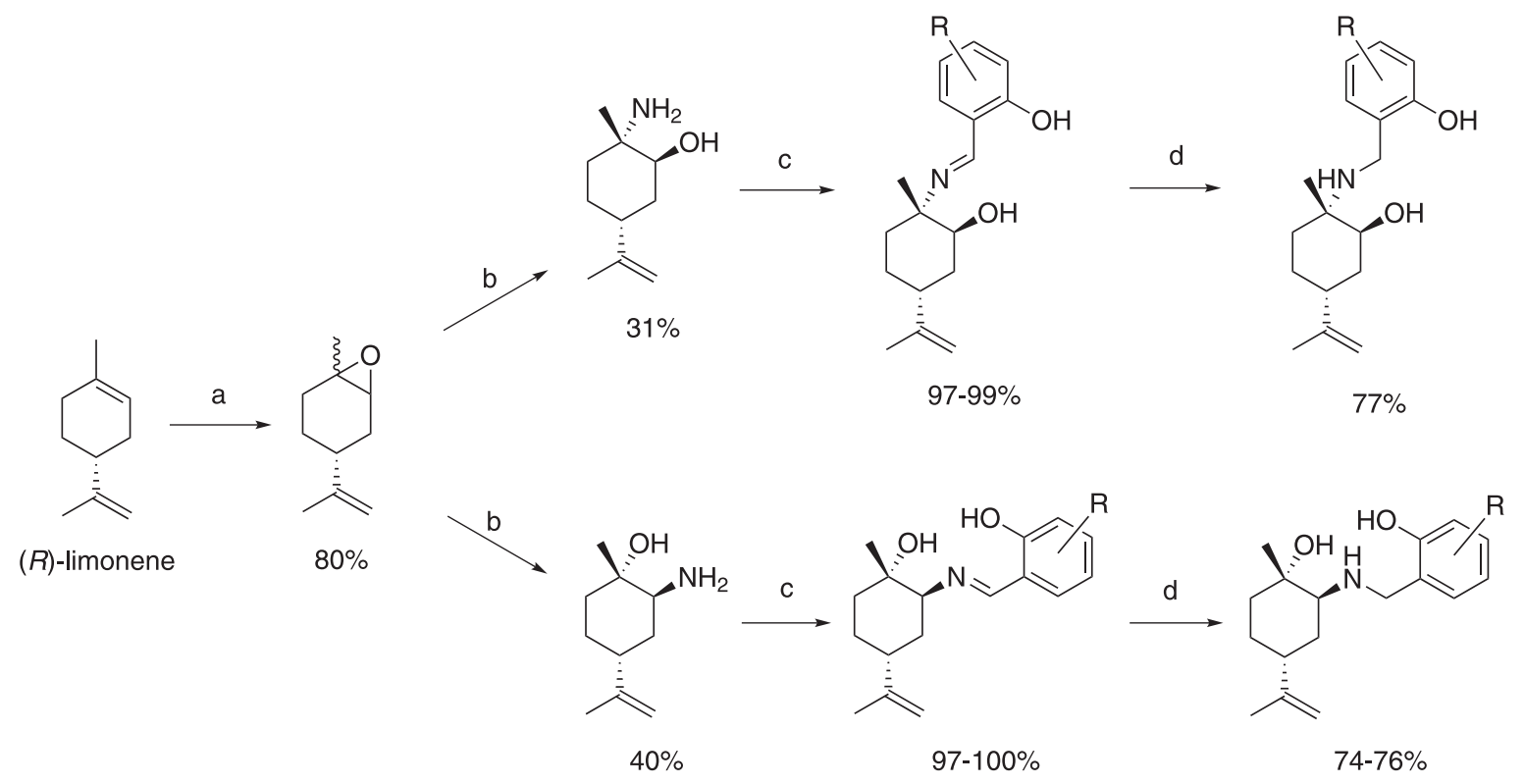

(a) $\mathrm{H}_{2} \mathrm{O}_{2}, \mathrm{MeReO}_{3}$; (b) 1) $\mathrm{NaN}_{3}$, 2) $\mathrm{LiAlH}_{4}$; (c) $\mathrm{ArCHO}$; (d) $\mathrm{LiAlH}_{4}$.

Scheme 1. Present work overview.

mixture of cis and trans-limonene oxides $\mathbf{1}$ in good yield (Scheme 2). This mixture was then reacted with $\mathrm{NaN}_{3}$, using an adaptation of the methodology of Cimarelli et al..$^{32}$ As described by these researchers, the reaction was highly stereosselective and yielded only two products, the azidoalcohols $\mathbf{2 a}$ and $\mathbf{2 b}$, bearing trans carbon substituents in the cyclohexyl ring, which could be separated by flash column chromatography. This reaction pattern is very common for limonene oxide ring opening by nucleophiles and is due to the ring strain during the transition state and therefore is used for the kinetic separation of these oxides. $^{33,34}$ Through the reduction of the azide group with $\mathrm{LiAlH}_{4}$ in tetrahydrofuran (THF), primary amines $\mathbf{3 a}$ and 3b were obtained in high yields. These derivatives were characterized by ${ }^{1} \mathrm{H}$ and ${ }^{13} \mathrm{C}$ nuclear magnetic resonance (NMR) and the spectra matched very well the ones of their enantiomers, which are described in the literature. ${ }^{32}$

With the primary amines $\mathbf{3 a - b}$ in hands, we proceeded to the imine formation reaction with three different $\mathrm{OH}$-substituted aromatic aldehydes. These reactions produced the desired Schiff bases (4-6a and 4-6b) in excellent yields and in short reaction times (Scheme 3). It is worth pointing out that the acidity of the phenolic group itself was the catalyst for this reaction and provided an optimum $\mathrm{pH}$ for the reaction to take place, since there was no need to use another catalyst or water removal to dislocate

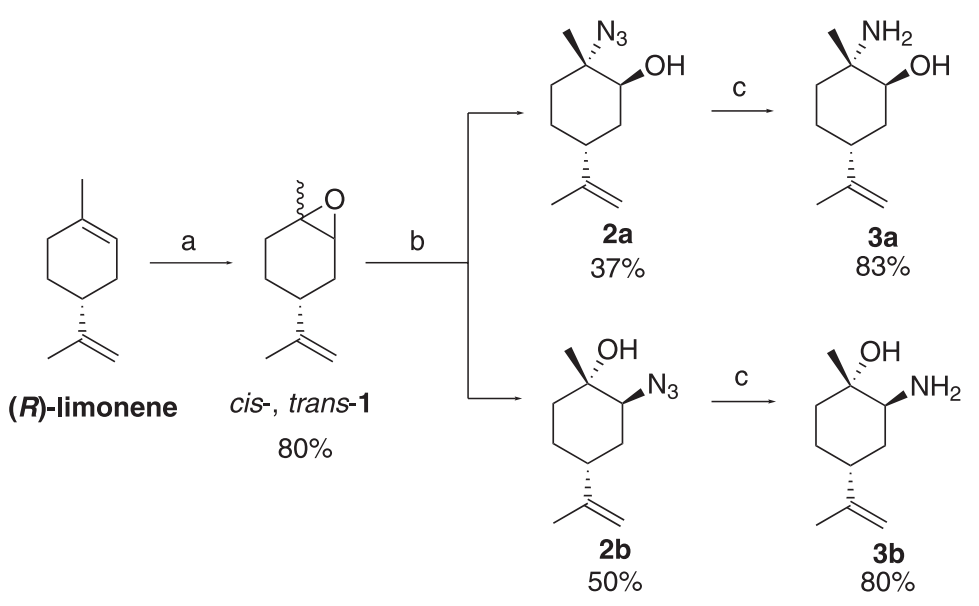

(a) $10 \% \mathrm{H}_{2} \mathrm{O}_{2}$ (aq), $1 \mathrm{~mol} \% \mathrm{MTO}, \mathrm{DCM}, 4^{\circ} \mathrm{C}$; (b) $\mathrm{NaN}_{3}, \mathrm{NH}_{4} \mathrm{Cl}, \mathrm{MeOH}$, reflux, $30 \mathrm{~h}$; (c) $\mathrm{LiAlH}_{4}, \mathrm{THF}, \mathrm{rt}, 1 \mathrm{~h}, \mathrm{~N}_{2}(\mathrm{~g})$. 
the reaction equilibrium to the products. The phenolic $\mathrm{OH}$ group present in these compounds could be useful in catalysis or medicinal chemistry, by providing an additional number of possible interactions to metals or biomolecules active sites. All of these compounds were characterized by mass spectroscopy, polarimetry, infrared spectroscopy (IR), ${ }^{1} \mathrm{H}$ and ${ }^{13} \mathrm{C}$ NMR. The most important change on the ${ }^{1} \mathrm{H}$ NMR spectra of these compounds was the appearance of the imine $\mathrm{N}=\mathrm{C}-\mathrm{H}$ signal at about $8.5 \mathrm{ppm}$, along with the incorporation of the aromatic and phenolic hydrogens.

Single crystals of $\mathbf{5} \mathbf{a}$ and $\mathbf{6} \mathbf{a}$ suitable to X-ray diffraction studies were grown by slow evaporation of the solvent from a concentrated dichloromethane (DCM)/hexane solution of the compounds and provided additional information about their molecular structures. The molecular structures of 5a and 6a are shown in Figures 1 and 2, respectively. The main crystallographic data and structure refinement parameters are reported in the Supplementary Information
(SI) section. Compound 5a (Figure 1) has three stereogenic centers and the absolute configuration was determined to be $\mathrm{C} 13(S), \mathrm{C} 14(S), \mathrm{C} 16(R)$ by considering the synthetic pathway and confirmed by the X-ray diffraction study. Moreover, the solid-state structure of 5a reveals that the imine group are in $E$ configuration and the torsion angle between C6-C12-N-C13 is 176.55(32). Compound $6 \mathbf{a}$ (Figure 2) has also three chiral centers with the absolute configuration determined as $\mathrm{C} 12(S), \mathrm{C} 15(R), \mathrm{C} 17(S)$, which is consistent with the synthetic pathway and confirmed by the X-ray diffraction analysis. Like 5a, the imine group in 6a are in $E$ configuration and the torsion angle between C12-N1-C11-C10 is $175.38(14)$.

To increase the structural variation of the compounds, we performed the reduction of the imines with $\mathrm{LiAlH}_{4}$ (Scheme 4). Although the reaction occurred in good yield with imines $\mathbf{4 - 5 a}$ and $\mathbf{4 - 5} \mathbf{b}$, it was not the case for the naphtyl derivatives, which produced a complex mixture<smiles>C=C(C)[C@@H]1CC[C@@](C)(N)[C@H](O)C1</smiles>

$3 a$<smiles>O=Cc1ccccc1O</smiles><smiles>Cc1cc(C=O)c(O)c(C(C)(C)C)c1</smiles>

or<smiles>O=Cc1c(O)ccc2ccccc12</smiles><smiles>C=C(C)[C@@H]1CC[C@@](C)(N=Cc2ccccc2O)[C@H](O)C1</smiles>

4a: $98 \%$<smiles>C=C(C)[C@@H]1CC[C@@](C)(O)[C@H](/N=C/c2ccccc2O)C1</smiles>

4b: $100 \%$<smiles>C=C(C)[C@@H]1CC[C@@](C)(N=Cc2cc(C)cc(C(C)(C)C)c2O)[C@H](O)C1</smiles>

5a: $99 \%$<smiles>C=C(C)[C@@H]1CC[C@@](C)(O)[C@H](/N=C/c2cc(C)cc(C(C)(C)C)c2O)C1</smiles>

5b: $94 \%$<smiles>C=C(C)[C@@H]1CC[C@@](C)(N=Cc2c(O)ccc3ccccc23)[C@H](O)C1</smiles>

6a: $97 \%$

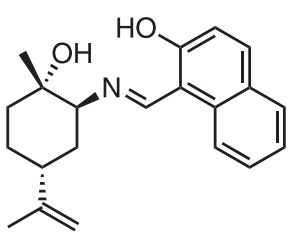

6b: $97 \%$ 


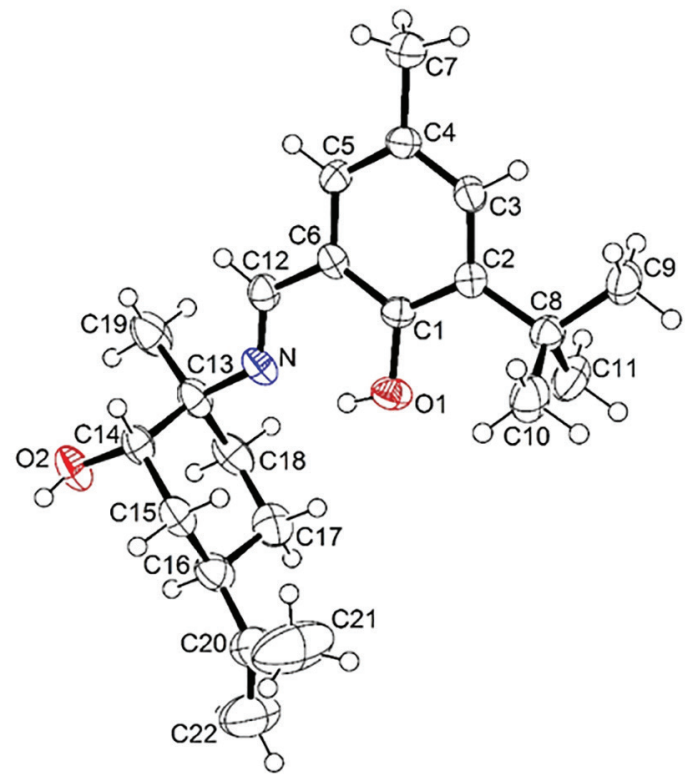

Figure 1. Molecular structure of $\mathbf{5 a}$ with the key atoms labelled (thermal ellipsoids drawn at $50 \%$ probability level).

along with some unreacted starting material. All of these compounds were characterized by mass spectroscopy, polarimetry, infrared spectroscopy, ${ }^{1} \mathrm{H}$ and ${ }^{13} \mathrm{C}$ NMR. The most important change on the ${ }^{1} \mathrm{H}$ NMR spectra of these derivatives was disappearance of the imine $\mathrm{N}=\mathrm{C}-\mathrm{H}$ signal at about $8.5 \mathrm{ppm}$.

In summary, we obtained 4 enantiomers of compounds that were previously described in the literature (2a-b and 3a-b). ${ }^{32}$ We also described the synthesis of 6 new iminoalcohols and 4 new amino-alcohols, all based on the terpene

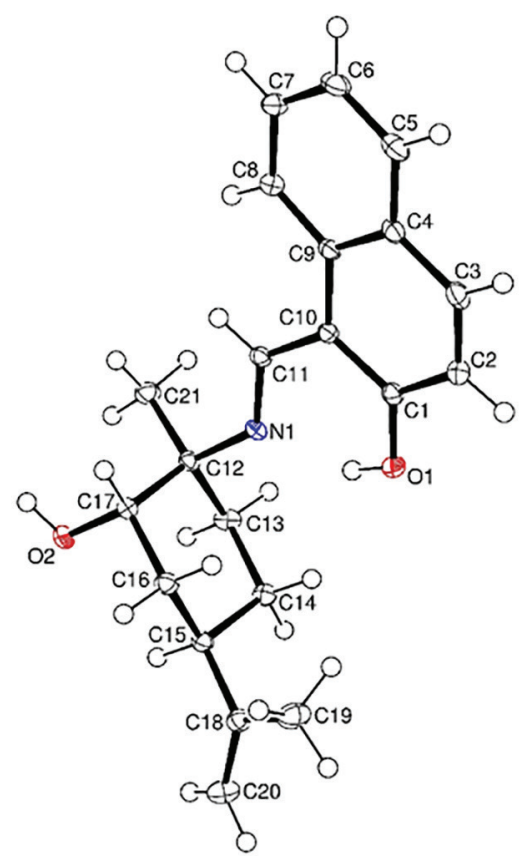

Figure 2. Molecular structure of $\mathbf{6 a}$ with the key atoms labelled (thermal ellipsoids drawn at 50\% probability level).

$(R)$-limonene, through simple reactions with good overall yields.

\section{Conclusions}

Primary amino-alcohol ligands were obtained by epoxidation of $(R)$-limonene with $\mathrm{MTO} / \mathrm{H}_{2} \mathrm{O}_{2}$, followed by epoxy-opening reactions with sodium azide and reduction<smiles>C=C(C)[C@@H]1CC[C@@](C)(N=Cc2ccccc2O)[C@H](O)C1</smiles>

$4 a$<smiles>C=C(C)[C@@H]1CC[C@@](C)(N=Cc2cc(C)cc(C(C)(C)C)c2O)[C@H](O)C1</smiles>

$5 a$

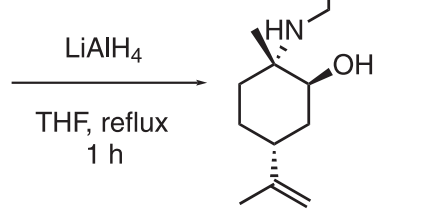

7a: $77 \%$<smiles>C=C(C)[C@@H]1CC[C@@](C)(O)[C@H](/N=C/c2ccccc2O)C1</smiles>

$4 b$

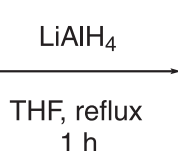<smiles>C=C(C)[C@@H]1CC[C@@](C)(O)[C@H](N=Cc2cc(C)cc(C(C)(C)C)c2O)C1</smiles>

$5 b$<smiles>C=C(C)[C@@H]1CC[C@@](C)(O)[C@H](NCc2ccccc2O)C1</smiles>

7b: $76 \%$

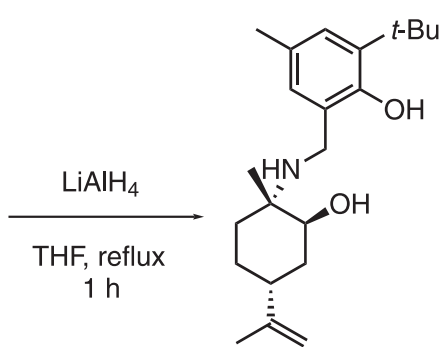

8a: $77 \%$

Scheme 4. Imine reduction reactions. 
with $\mathrm{LiAlH}_{4}$. From these, imines were formed by reacting with three aromatic salicylaldehydes in excellent yields. Some imines were reduced to secondary amino-alcohols. The compounds were extensively characterized by NMR, IR, high resolution mass spectroscopy (HRMS) and polarimetry, and it was possible to solve the crystal structure of two of them through single crystal X-ray diffraction (XRD). The reactions proceeded smoothly and with great yields. With these procedures, we were able to achieve new imino- and amino-alcohols, which could be useful in catalysis, medicinal chemistry or even in other applications. This study is under way.

\section{Experimental}

\section{General}

Unless otherwise stated, all reagents and solvents were used as received. THF was dried through distillation from Nabenzophenone. NMR experiments were performed in a 300 or $400 \mathrm{MHz}$ Varian spectrometer. Fourier-transform infrared spectroscopy/attenuated total reflection (FTIR/ATR) analyses were performed in a Bruker alpha-P apparatus in ATR mode or Shimazdu IR Prestige-21 as thin films between $\mathrm{KBr}$ crystals. The NMR chemical shifts are given in ppm relatively to tetramethylsilane (TMS) and the FTIR wavenumbers are given in $\mathrm{cm}^{-1}$. Mass spectra were recorded on a Micromass Q-TOF Micro operating in electrospray mode. Polarimetry analyses were performed in a Jasco P2000 polarimeter in chloroform.

\section{Synthesis of cis- and trans-(+)-limonene oxides (1)}

The procedure was based on the literature. ${ }^{24}$ To $15.4 \mathrm{mg}$ of MTO $(0.0613 \mathrm{mmol})$, in an ice bath, $5 \mathrm{~mL}$ of dichloromethane (DCM) and $0.99 \mathrm{~mL}$ of $(R)$-limonene $(6.13 \mathrm{mmol})$ were added. Then $2.90 \mathrm{~mL}$ of a $3.18 \mathrm{M}$ aqueous $\mathrm{H}_{2} \mathrm{O}_{2}$ (1.5 equiv.) were added and the reaction was stirred in an ice bath for $1 \mathrm{~h}$. Then, the oxidant excess was destroyed with a small amount of $\mathrm{MnO}_{2}$. The organic phase was separated, and the aqueous layer was extracted with $1 \times 10 \mathrm{~mL}$ and $2 \times 5 \mathrm{~mL}$ of DCM. The organic layers were combined, dried with $\mathrm{Na}_{2} \mathrm{SO}_{4}$ and the solvent removed under vacuum. The product was purified by silica flash column chromatography using 5\% ethyl acetate (EtOAc) in hexane as elutant (thin layer chromatography (TLC), $\mathrm{t}_{\mathrm{R}}=0.5,5 \%$ EtOAc in hexane, using $\mathrm{KMnO}_{4}$ basic solution as developer). The solvent was carefully evaporated in a rotatory evaporator to give $\mathbf{1}$ as a colourless volatile oil. Yield: $746 \mathrm{mg}(80 \%)$.
(4R)-1-Methyl-4-(prop-1-en-2-yl)-7-oxabicyclo [4.1.0]heptane

${ }^{1} \mathrm{H}$ NMR $\left(300 \mathrm{MHz}, \mathrm{CDCl}_{3}\right) \delta$ 4.76-4.53 (m, 4H, cis + trans $), 3.01(\mathrm{t}, 1 \mathrm{H}, J 2.0$, cis $), 2.95(\mathrm{~d}, 1 \mathrm{H}, J$ 5.3, trans), 2.15-1.92 (m, 5H, cis + trans), 1.89-1.76 (m, 4H, cis + trans $), 1.73-1.58(\mathrm{~m}, 9 \mathrm{H}$, cis + trans $), 1.56-1.44(\mathrm{~m}$, $1 \mathrm{H}$, cis + trans $), 1.39-1.30(\mathrm{~m}, 2 \mathrm{H}$, cis + trans $), 1.28(\mathrm{~s}$, $3 \mathrm{H}$, cis), 1.27 (s, 3H, trans).

Synthesis of $(1 S, 2 S, 4 R)$-2-azido-1-methyl-4-(pro-1-en2-yl)cyclohexanol (2a) and (1S,2S,5R)-2-azido-2-methyl5-(prop-1-en-2-yl)cyclohexanol (2b)

The procedure was based on the literature. ${ }^{25} 1.52 \mathrm{~g}$ of $1(10 \mathrm{mmol}), 1.3 \mathrm{~g}$ of $\mathrm{NaN}_{3}(20 \mathrm{mmol})$ and $0.54 \mathrm{~g}$ of $\mathrm{NH}_{4} \mathrm{Cl}(10 \mathrm{mmol})$ were refluxed in $4 \mathrm{~mL}$ of methanol $(\mathrm{MeOH})$ until all limonene oxide was consumed according to TLC (about $32 \mathrm{~h}$ ). The mixture was allowed to cool to room temperature and the solvent removed. Then, DCM was added, and the mixture was filtered through $\mathrm{Na}_{2} \mathrm{SO}_{4}$ and evaporated. The azido-alcohols were separated by silica flash column chromatography using 10-30\% ether in hexane as gradient elutant (TLC: $t_{R}=0.45(\mathbf{2 a})$ and 0.3 (2b), $\mathrm{KMnO}_{4}$ as developer). After solvent removal, the azido-alcohols were obtained as pale-yellow oils. Yield: 2a $594 \mathrm{mg}$ (37\%) and $\mathbf{2 b} 822 \mathrm{mg}$ (50\%).

\section{Compound 2a}

${ }^{1} \mathrm{H}$ NMR $\left(300 \mathrm{MHz}, \mathrm{CDCl}_{3}\right) \delta$ 4.76-4.70 (m, 2H), 3.64 $(\mathrm{t}, 1 \mathrm{H}, J 3.3), 2.25$ (tt, $1 \mathrm{H}, J 10.8,3.3), 1.95-1.40(\mathrm{~m}, 10 \mathrm{H})$, $1.36(\mathrm{~s}, 3 \mathrm{H}) ;{ }^{13} \mathrm{C}$ NMR $\left(75 \mathrm{MHz}, \mathrm{CDCl}_{3}\right) \delta 149.0,109.1$, 71.9, 63.1, 37.1, 34.1, 30.8, 26.4, 22.6, 20.8.

\section{Compound 2b}

${ }^{1} \mathrm{H}$ NMR (400 MHz, $\left.\mathrm{CDCl}_{3}\right) \delta 4.77(\mathrm{~s}, 2 \mathrm{H}), 3.54(\mathrm{~s}$, $1 \mathrm{H}$ ), 2.20 (ddd, $1 \mathrm{H}, J 14.8,9.8,3.9$ ), 2.00 (ddd, $1 \mathrm{H}, J 14.8$, $11.9,3.0), 1.90-1.81(\mathrm{~m}, 1 \mathrm{H}), 1.76(\mathrm{~s}, 3 \mathrm{H}), 1.72-1.61(\mathrm{~m}$, $1 \mathrm{H}), 1.62-1.36(\mathrm{~m}, 5 \mathrm{H}), 1.30(\mathrm{~s}, 3 \mathrm{H}) ;{ }^{13} \mathrm{C}$ NMR $(101 \mathrm{MHz}$, $\left.\mathrm{CDCl}_{3}\right) \delta 148.7,109.2,70.9,66.4,37.9,33.9,30.7,27.6$, 25.92, 20.95.

Synthesis of $(1 S, 2 S, 5 R)$-2-amino-2-methyl-5-(prop-1-en2-yl)cyclohexanol (3a)

The procedure was based on the literature. ${ }^{25}$ Under argon atmosphere, $2 \mathrm{~mL}$ of dry THF were added on $200 \mathrm{mg}$ of $\mathrm{LiAlH}_{4}(5.26 \mathrm{mmol})$ in an ice bath. Then, a solution of $699 \mathrm{mg}$ of $2 \mathbf{a}(3.58 \mathrm{mmol})$ in $3 \mathrm{~mL}$ of dry THF was slowly added, causing $\mathrm{N}_{2}$ evolution, and the mixture was stirred for $1 \mathrm{~h}$ in room temperature. The reaction was quenched with saturated $\mathrm{Na}_{2} \mathrm{SO}_{4}(\mathrm{aq})$, then $10 \mathrm{~mL}$ of DCM were 
added, along with $\mathrm{MgSO}_{4}$. The mixture was filtered and the solid washed with $5 \times 5 \mathrm{~mL}$ of DCM. The filtrate was dried under vacuum to give $\mathbf{3 a}$ as a white crystalline solid. Yield: $488 \mathrm{mg}(81 \%)$.

${ }^{1} \mathrm{H}$ NMR $\left(400 \mathrm{MHz}, \mathrm{CDCl}_{3}\right) \delta 4.68(\mathrm{~s}, 2 \mathrm{H}), 3.47(\mathrm{~s}, 1 \mathrm{H})$, 2.23 (ddd, $1 \mathrm{H}, J 14.7,10.0,3.9$ ), 1.79 (dddd, $1 \mathrm{H}, J 13.8,10.9$, $3.0,1.3), 1.72-1.49\left(\mathrm{~m}, 9 \mathrm{H}+\mathrm{H}_{2} \mathrm{O}\right), 1.49-1.36(\mathrm{~m}, 1 \mathrm{H}), 1.36-1.24$ $(\mathrm{m}, 1 \mathrm{H}), 1.07$ (d, 3H, $J 1.3) ;{ }^{13} \mathrm{C}$ NMR $\left(75 \mathrm{MHz}, \mathrm{CDCl}_{3}\right)$ $\delta$ 149.1, 109.1, 71.9, 55.4, 37.5, 34.4, 33.7, 26.2, 25.8, 21.2.

Synthesis of $(1 S, 2 S, 4 R)$-2-amino-1-methyl-4-(prop-1-en2-yl)ciclohexanol (3b)

The procedure was identical to the synthesis of $\mathbf{3 a}$, using $717 \mathrm{mg}$ of $\mathbf{2 b}$ (3.67 mmol). Yield: $519 \mathrm{mg}(84 \%)$. The product was obtained as a pale-yellow solid.

${ }^{1} \mathrm{H}$ NMR (400 MHz, $\mathrm{CDCl}_{3}$ ) $\delta 4.68(\mathrm{~s}, 2 \mathrm{H}), 3.52-3.44$ $(\mathrm{m}, 1 \mathrm{H}), 2.22(\mathrm{td}, 1 \mathrm{H}, J 10.3,5.0), 1.85-1.50\left(\mathrm{~m}, 9 \mathrm{H}+\mathrm{H}_{2} \mathrm{O}\right)$, 1.49-1.39 (m, 1H), 1.33 (dddd, $1 \mathrm{H}, J 13.3,4.9,3.6,1.1$ ), 1.08 (s, 3H); ${ }^{13} \mathrm{C}$ NMR $\left(75 \mathrm{MHz}, \mathrm{CDCl}_{3}\right) \delta 149.1,109.1$, 74.5, 51.6, 37.6, 34.5, 33.7, 26.4, 26.1, 21.3.

Synthesis of 2-((E)-(((1S,2S,4R)-2-hydroxy-1-methyl4-(prop-1-en-2-yl)cyclohexyl)imino)methyl)phenol (4a)

$86.3 \mathrm{mg}$ of $3 \mathbf{a}(0.51 \mathrm{mmol})$ and $55 \mu \mathrm{L}$ of salicylaldehyde $(0.51 \mathrm{mmol})$ were stirred in $2 \mathrm{~mL}$ of $\mathrm{EtOH}$ at room temperature until 3a was completely consumed according to TLC (20 min, $20 \% \mathrm{MeOH}$ in DCM, $\mathrm{t}_{\mathrm{R}}=0.5, \mathrm{KMnO}_{4}$ as developer). The solvent was removed and the product purified with silica flash column chromatography using gradient elution with 5-20\% EtOAc in hexane (TLC: 15\% EtOAc in hexane, $t_{R}=0.35$, using vanillin acidic solution as developer). Yield: $137 \mathrm{mg}$ (98\%) of a bright yellow oil.

$[\alpha]_{D}{ }^{25}+31.7^{\circ}\left(c \quad 0.427, \mathrm{CHCl}_{3}\right) ;{ }^{1} \mathrm{H}$ NMR $(400 \mathrm{MHz}$, $\left.\mathrm{CDCl}_{3}\right) \delta 14.13(\mathrm{~s}, 1 \mathrm{H}), 8.46(\mathrm{~s}, 1 \mathrm{H}), 7.40-7.23(\mathrm{~m}, 2 \mathrm{H}), 6.99$ (d, 1H, J 8.2), 6.91 (t, 1H, J 7.4), 4.75 (s, 2H), 3.82 (s, 1H), 2.42 (tt, $1 \mathrm{H}, J 11.9,3.9$ ), 1.95 (ddt, $2 \mathrm{H}, J 14.4,12.8,2.2$ ), 1.80 $(\mathrm{td}, 1 \mathrm{H}, J 3.9,1.8), 1.78-1.70(\mathrm{~m}, 5 \mathrm{H}), 1.69-1.47(\mathrm{~m}, 2 \mathrm{H})$, 1.34 (s, 3H); ${ }^{13} \mathrm{C}$ NMR (100 MHz, $\left.\mathrm{CDCl}_{3}\right) \delta 161.9,161.6$, 149.1, 132.3, 131.5, 118.9, 118.4, 117.2, 109.2, 74.2, 61.7, 37.4, 34.1, 32.4, 26.1, 23.8, 20.8; FTIR $v / \mathrm{cm}^{-1} 3421,3075$, 2938, 1625, 889, 755; HRMS (FTMS + pESI) $\mathrm{m} / z$, calculated for $\mathrm{C}_{17} \mathrm{H}_{23} \mathrm{NO}_{2} \mathrm{H}[\mathrm{MH}]^{+}:$274.1807, found: 274.1807.

Synthesis of 2-((E)-(((1S,2S,5R)-2-hydroxy-2-methyl5-(prop-1-en-2-yl)cyclohexyl)imino)methyl)phenol (4b)

The procedure was identical to the synthesis of $\mathbf{4 a}$, using $\mathbf{3 b}$ as substract. The product was purified with silica flash column chromatography using gradient elution with $5-20 \%$
EtOAc in hexane as elutant (TLC: $15 \%$ EtOAc in hexane, $t_{R}=0.35$, vanillin as developer). Yield: $139 \mathrm{mg}(100 \%)$ of a bright yellow oil.

$[\alpha]_{\mathrm{D}}{ }^{25}-166.3^{\circ}$ ( c 0.325, $\mathrm{CHCl}_{3}$ ); ${ }^{1} \mathrm{H}$ NMR (400 MHz, $\left.\mathrm{CDCl}_{3}\right) \delta 13.49(\mathrm{~s}, 1 \mathrm{H}), 8.29(\mathrm{~s}, 1 \mathrm{H}), 7.28-7.16(\mathrm{~m}, 2 \mathrm{H})$, 6.89 (d, 1H, J 8.2), 6.81 (td, 1H, J 7.5, 1.1), 4.68-4.61 (m, $2 \mathrm{H}), 3.20(\mathrm{t}, 1 \mathrm{H}, J 3.1), 2.33-2.21(\mathrm{~m}, 1 \mathrm{H}), 2.08$ (ddd, $1 \mathrm{H}$, $J 13.3,12.2,3.3), 1.89-1.75(\mathrm{~m}, 1 \mathrm{H}), 1.22-1.54(\mathrm{~m}, 6 \mathrm{H}), 1.50$ (ddt, $1 \mathrm{H}, J 13.3$, 3.7. 2.2) 1.03 (s, $3 \mathrm{H}) ;{ }^{13} \mathrm{C}$ NMR $(100 \mathrm{MHz}$, $\left.\mathrm{CDCl}_{3}\right) \delta 164.1,161.1,149.4,132.4,131.4,118.8,118.8$, 117.0, 109.0, 74.3, 70.8, 38.2, 34.9, 34.8, 28.3, 26.5, 21.1; IR $(\mathrm{KBr}) \mathrm{v} / \mathrm{cm}^{-1} 3425,2929,2864,1631,1496,1276,756$, 433; HRMS (FTMS + pESI) $m / z$, calculated for $\mathrm{C}_{17} \mathrm{H}_{23} \mathrm{NO}_{2} \mathrm{H}$ $[\mathrm{MH}]^{+}:$274.1807, found: 274.1807.

Synthesis of 2-(tert-butyl)-6-((E)-(((1S,2S,4R)-2-hydroxy1-methyl-4-(prop-1-en-2-yl)cyclohexyl)imino)methyl)4-methylphenol (5a)

$83 \mathrm{mg}$ of $3 \mathbf{a}(0.48 \mathrm{mmol})$ and $96 \mathrm{mg}$ of 3-(tert-butyl)2-hydroxy-5-methylbenzaldehyde $(0.5 \mathrm{mmol})$ were stirred in $2 \mathrm{~mL}$ of EtOH until all 3a was consumed according to TLC (1 h $30 \mathrm{~min})$. The mixture was vacuum dried and purified by silica flash column chromatography using 0-10\% EtOAc in hexane as elutant. Yield: $167.9 \mathrm{mg}$ (99\%) of a yellow crystalline solid.

$[\alpha]_{\mathrm{D}}{ }^{25}-17.0^{\circ}$ (c 0.456, $\mathrm{CHCl}_{3}$ ); ${ }^{1} \mathrm{H}$ NMR $(400 \mathrm{MHz}$, $\left.\mathrm{CDCl}_{3}\right) \delta 4.23(\mathrm{~s}, 1 \mathrm{H}), 8.40(\mathrm{~s}, 1 \mathrm{H}), 7.13(\mathrm{~d}, 1 \mathrm{H}, J 2.2), 6.95$ (d, $1 \mathrm{H}, J 1.5), 4.78-4.68(\mathrm{~m}, 2 \mathrm{H}), 3.83(\mathrm{~s}, 1 \mathrm{H}), 2.47-2.33$ (m, 1H), 2.29 (s, 3H), 2.02-1.85 (m, 2H), 1.78-1.74 (m, $1 \mathrm{H}), 1.57(\mathrm{~m}, 7 \mathrm{H}), 1.43(\mathrm{~s}, 9 \mathrm{H}), 1.30(\mathrm{~s}, 3 \mathrm{H}) ;{ }^{13} \mathrm{C} \mathrm{NMR}$ $\left(101 \mathrm{MHz}, \mathrm{CDCl}_{3}\right) \delta 162.5,158.3,14.5,137.3,130.4$, 129.8, 126.4, 118.6, 109.2, 74.4, 61.5, 37.5, 34.8, 34.1, 32.3, 29.4, 26.1, 23.9, 20.7, 20.6; IR (KBr) $v / \mathrm{cm}^{-1} 3508$, 2939, 2858, 1620, 1440, 876; HRMS (FTMS + pESI) $m / z$, calculated for $\mathrm{C}_{22} \mathrm{H}_{33} \mathrm{NO}_{2} \mathrm{H}[\mathrm{MH}]^{+}: 344.2589$, found: 344.2586; melting point: $110^{\circ} \mathrm{C}$.

Synthesis of 2-(tert-butyl)-6-((E)-(((1S,2S,5R)-2-hydroxy2-methyl-5-(prop-1-en-2-yl)cyclohexyl)imino)methyl)4-methylphenol (5b)

The procedure was identical to the synthesis of $\mathbf{6 a}$, using $\mathbf{3 b}$. The product was purified by silica flash column chromatography using 10-30\% EtOAc in hexane as elutant. $\left(t_{R}=0.5,20 \%\right.$ EtOAc in hexane, vanillin as developer $)$. Yield: $158 \mathrm{mg}(94 \%)$ of a yellow viscous material.

$[\alpha]_{\mathrm{D}}{ }^{25}-24.8^{\circ}$ (c 0.584, $\mathrm{CHCl}_{3}$ ); ${ }^{1} \mathrm{H}$ NMR $(300 \mathrm{MHz}$, $\left.\mathrm{CDCl}_{3}\right) \delta 13.50(\mathrm{~s}, 1 \mathrm{H}), 8.33(\mathrm{~s}, 1 \mathrm{H}), 7.14(\mathrm{~d}, 1 \mathrm{H}, J 1.8)$, 6.94 (d, 1H, J 1.8), 4.76-4.69 (m, 2H), 3.25 (t, 1H, J 2.9), 2.49-2.32 (m, 1H), 2.29 (s, 3H), 2.13 (ddd, 1H, J 13.2, 12.2, 
3.3), 1.81-1.51 (m, 9H), 1.44 (s, 9H), $1.12(\mathrm{~s}, 3 \mathrm{H}) ;{ }^{13} \mathrm{C} \mathrm{NMR}$ $\left(101 \mathrm{MHz}, \mathrm{CDCl}_{3}\right) \delta 178.1,153.7,148.3,137.9,134.0$, 129.3, 128.0, 126.0, 125.5, 122.7, 117.5, 109.7, 106.5, 73.0, 59.7, 37.2, 34.1, 32.4, 25.8, 23.8, 21.0; IR (KBr) $\mathrm{v} / \mathrm{cm}^{-1} 3428,2947,1620,1432,888,753$; HRMS (FTMS + pESI) $\mathrm{m} / z$, calculated for $\mathrm{C}_{22} \mathrm{H}_{33} \mathrm{NO}_{2} \mathrm{H}[\mathrm{MH}]^{+}$: 344.2589, found: 344.2589 .

Synthesis of 1-((E)-(((1S,2S,4R)-2-hydroxy-1-methyl4-(prop-1-en-2-yl)cyclohexyl)imino)methyl)naphtalen-2-ol (6a)

$130.8 \mathrm{mg}$ of $\mathbf{3 a}(0.773 \mathrm{mmol})$ and $137.1 \mathrm{mg}$ of 2-hydroxy-1-naphtaldehyde $(0.77 \mathrm{mmol})$ were solubilized in $5 \mathrm{~mL}$ of EtOH and stirred at room temperature until all 3a was consumed (about $15 \mathrm{~min}$ ). The mixture was dried in vacuum and then purified by silica flash column chromatography using 20-40\% EtOAc in hexane as elutant. Yield: $242 \mathrm{mg}$ (97\%) of an orange crystalline solid.

$[\alpha]_{\mathrm{D}}{ }^{25}+83.1^{\circ}\left(c\right.$ 0.596, $\left.\mathrm{CHCl}_{3}\right) ;{ }^{1} \mathrm{H}$ NMR $(400 \mathrm{MHz}$, $\left.\mathrm{CDCl}_{3}\right) \delta 14.99(\mathrm{~s}, 1 \mathrm{H}), 8.80(\mathrm{~d}, 1 \mathrm{H}, J$ 8.4), $7.81(\mathrm{~d}, 1 \mathrm{H}$, $J$ 8.4), 7.66 (d, 1H, J 9.3), 7.58 (d, 1H, J 7.8), 7.41 (ddd, 1H, $J$ 8.3, 7.1, 1.2), 7.25-7.17 (m, 1H), $6.90(\mathrm{~d}, 1 \mathrm{H}, J 9.3 \mathrm{~Hz})$, 4.76 (d, 2H, J 5.7), 3.89 (s, 1H), 3.34- 2.93 (m, 1H), 2.44 (ddd, $1 \mathrm{H}, J 14.5,10.8,3.6), 2.11-1.90(\mathrm{~m}, 2 \mathrm{H}), 1.90-1.78$ $(\mathrm{m}, 2 \mathrm{H}), 1.78-1.55(\mathrm{~m}, 5 \mathrm{H}), 1.49(\mathrm{~s}, 3 \mathrm{H}) ;{ }^{13} \mathrm{C} \mathrm{NMR}$ $\left(101 \mathrm{MHz}, \mathrm{CDCl}_{3}\right) \delta 178.1,153.7,148.3,137.9,134.0$, $129.3,128.0,126.0,125.5,122.7,117.5,109.7,106.5$, 73.0, 59.7, 37.2, 34.1, 32.4, 25.8, 23.8, 21.0; IR (KBr) $v / \mathrm{cm}^{-1} 3258,2925,2852,1616,1341,759$; HRMS (FTMS + pESI) $m / z$, calculated for $\mathrm{C}_{21} \mathrm{H}_{25} \mathrm{NO}_{2} \mathrm{H}[\mathrm{MH}]^{+}$: 324.1964, found: 324.1963 ; melting point: $138^{\circ} \mathrm{C}$.

Synthesis of 1-((E)-(((1S,2S,5R)-2-hydroxy-2-methyl5-(prop-1-en-2-yl)cyclohexyl)imino)methyl)naphtalen-2-ol (6b)

The procedure was identical to the synthesis of $\mathbf{5 a}$, using $84.7 \mathrm{mg}(0.50 \mathrm{mmol})$ of $\mathbf{3 b}$. Yield: $156.9 \mathrm{mg}(97 \%)$ of an orange viscous material.

$[\alpha]_{\mathrm{D}}{ }^{25}+33.0^{\circ}\left(c \quad 0.562, \mathrm{CHCl}_{3}\right) ;{ }^{1} \mathrm{H}$ NMR $(400 \mathrm{MHz}$, $\left.\mathrm{CDCl}_{3}\right) \delta 15.17(\mathrm{~s}, 1 \mathrm{H}), 8.88(\mathrm{~s}, 1 \mathrm{H}), 7.93(\mathrm{~d}, 1 \mathrm{H}, J 8.3), 7.72$ (d, 1H, J 9.2), $7.64(\mathrm{~d}, 1 \mathrm{H}, J 7.9), 7.46(\mathrm{t}, 1 \mathrm{H}, J 7.7), 7.26(\mathrm{t}$, $1 \mathrm{H}, J$ 7.4), 6.99 (d, 1H, J 9.2), 4.77 (d, 2H, J 4.6), 3.49 (s, $1 \mathrm{H}), 2.43-2.30(\mathrm{~m}, 1 \mathrm{H}), 2.23$ (td, $1 \mathrm{H}, J 12.4,3.2), 1.99-1.62$ (m, 9H + $\left.\mathrm{H}_{2} \mathrm{O}\right), 1.22(\mathrm{~s}, 3 \mathrm{H}) ;{ }^{13} \mathrm{C}$ NMR (101 MHz, $\mathrm{CDCl}_{3}$ ) $\delta 173.9,157.9,148.6,136.9,133.4,129.3,128.0,126.5$, 123.7, 123.0, 118.1, 109.5, 107.1, 70.7, 69.7, 38.2, 34.8, 33.7, 27.7, 26.2, 21.2; IR (KBr) $v / \mathrm{cm}^{-1} 3319,3058,2950$ 1616, 1027, 746; HRMS (FTMS + pESI) $\mathrm{m} / \mathrm{z}$, calculated for $\mathrm{C}_{21} \mathrm{H}_{25} \mathrm{NO}_{2} \mathrm{H}[\mathrm{MH}]^{+}:$324.1964, found: 324.1964 .
Synthesis of 2-((((1S,2S,4R)-2-hydroxy-1-methyl-4-(prop1-en-2-yl)cyclohexyl)amino)methyl)phenol (7a)

Under Ar atmosphere, $16 \mathrm{mg}$ of $\mathrm{LiAlH}_{4}(0.42 \mathrm{mmol})$ were suspended in $1 \mathrm{~mL}$ of dry THF and to this $58.1 \mathrm{mg}$ of $4 \mathbf{a}(0.17 \mathrm{mmol})$ were added. The reaction was stirred at reflux temperature for $1 \mathrm{~h}$ and allowed to cool to room temperature. The reaction was quenched with saturated $\mathrm{Na}_{2} \mathrm{SO}_{4}(\mathrm{aq})$, then $10 \mathrm{~mL}$ of DCM were added, along with $\mathrm{MgSO}_{4}$, the mixture was filtered and the solid washed with $5 \times 5 \mathrm{~mL}$ of DCM. The filtrate was dried under vacuum to give 7a. Yield: $36 \mathrm{mg}(77 \%)$ of a yellow viscous material.

$[\alpha]_{\mathrm{D}}{ }^{25}+20.4^{\circ}\left(c\right.$ 1.632, $\left.\mathrm{CHCl}_{3}\right) ;{ }^{1} \mathrm{H}$ NMR $(400 \mathrm{MHz}$, $\left.\mathrm{CDCl}_{3}\right) \delta 7.17(\mathrm{td}, 1 \mathrm{H}, J$ 7.9, 1.7), 7.01 (dd, 1H, J 7.4, 1.7), 6.84 (dd, $1 \mathrm{H}, J 7.9,1.2), 6.78(\mathrm{td}, 1 \mathrm{H}, J 7.4,1.2)$, 4.80-4.72 (m, 2H), 3.96-3.83 (m, 2H), 3.77-3.71 (m, 1H), 2.35 (tt, $1 \mathrm{H}, J 10.9,4.0), 1.92-1.81(\mathrm{~m}, 1 \mathrm{H}), 1.81-1.56(\mathrm{~m}$, $8 \mathrm{H}), 1.54-1.39(\mathrm{~m}, 1 \mathrm{H}), 1.26(\mathrm{~s}, 3 \mathrm{H}) ;{ }^{13} \mathrm{C}$ NMR $(75 \mathrm{MHz}$, $\left.\mathrm{CDCl}_{3}\right) \delta 158.0,148.7,128.8,128.2,123.2,119.2,116.5$, 109.4, 72.1, 55.6, 44.8, 37.4, 33.8, 30.2, 25.7, 21.8, 21.1; IR (KBr) $v / \mathrm{cm}^{-1} 3424,3015,2929,1277,765,667,466$; HRMS (FTMS + pESI) $\mathrm{m} / z$, calculated for $\mathrm{C}_{17} \mathrm{H}_{25} \mathrm{NO}_{2} \mathrm{H}$ $[\mathrm{MH}]^{+}: 276.1964$, found: 276.1964 .

Synthesis of 2-((((1S,2S,5R)-2-hydroxy-2-methyl-5-(prop1-en-2-yl)cyclohexyl)amino)methyl)phenol (7b)

The procedure was identical to the synthesis of $7 \mathbf{a}$, starting from $81 \mathrm{mg}(0.31 \mathrm{mmol})$ of $4 \mathrm{~b}$. Yield: $56 \mathrm{mg}(76 \%)$ of a light yellow viscous material.

$[\alpha]_{\mathrm{D}}{ }^{25}+26.4^{\circ}\left(c 1.028, \mathrm{CHCl}_{3}\right) ;{ }^{1} \mathrm{H}$ NMR $(400 \mathrm{MHz}$, $\left.\mathrm{CDCl}_{3}\right) \delta 7.18(\mathrm{td}, 1 \mathrm{H}, J 8.0,1.2), 7.01(\mathrm{dd}, 1 \mathrm{H}, J 7.4,0.7)$, 6.84 (dd, $1 \mathrm{H}, J$ 8.0, 0.7), 6.79 (td, $1 \mathrm{H}, J 7.4,1.2), 4.76$ (d, $2 \mathrm{H}, J 7.5), 4.07$ (d, 1H, J 13.6), 3.87 (d, 1H, J 13.6), 2.69 (t, $1 \mathrm{H}, J$ 4.0), 2.17-2.02 (m, 1H), 1.96 (ddd, $1 \mathrm{H}, J 14.0,10.8$, 3.3), $1.78-1.50(\mathrm{~m}, 9 \mathrm{H}), 1.30(\mathrm{~s}, 3 \mathrm{H}) ;{ }^{13} \mathrm{C} \mathrm{NMR}(101 \mathrm{MHz}$, $\left.\mathrm{CDCl}_{3}\right) \delta 158.0,148.4,128.9,128.3,123.0,119.3,116.4$, 109.6, 71.5, 61.8, 51.0, 37.8, 35.0, 29.9, 28.8, 26.0, 21.2; IR $(\mathrm{KBr}) v / \mathrm{cm}^{-1} 3425,3012,2933,1215,761,486$; HRMS (FTMS + pESI) $\mathrm{m} / z$, calculated for $\mathrm{C}_{17} \mathrm{H}_{25} \mathrm{NO}_{2} \mathrm{H}[\mathrm{MH}]^{+}$: 276.1964, found: 276.1962 .

Synthesis of 2-(tert-butyl)-6-((((1S,2S,4R)-2-hydroxy1-methyl-4-(prop-1-en-2-yl)cyclohexyl)amino)methyl)4-methylphenol (8a)

The procedure was identical to the synthesis of $\mathbf{7 a}$, starting from $58 \mathrm{mg}(0.16 \mathrm{mmol})$ of 5a. Yield: $45 \mathrm{mg}(77 \%)$ of a light yellow solid.

$[\alpha]_{\mathrm{D}}^{25}+15.3^{\circ}\left(c 0.180, \mathrm{CHCl}_{3}\right) ;{ }^{1} \mathrm{H}$ NMR $(400 \mathrm{MHz}$, $\left.\mathrm{CDCl}_{3}\right) \delta 6.99(\mathrm{~s}, 1 \mathrm{H}), 6.71(\mathrm{~s}, 1 \mathrm{H}), 4.76(\mathrm{~s}, 2 \mathrm{H}), 3.85$ 
(m, 2H), 3.74 (s, 1H), 2.43-2.29 (m, 1H), 2.24 (s, 3H), 1.95-1.79 (m, 2H), 1.72-1.45 (m, 10H), 1.40 (s, 9H), 1.26 (s, 3H); ${ }^{13} \mathrm{C} \mathrm{NMR}\left(101 \mathrm{MHz}, \mathrm{CDCl}_{3}\right) \delta 154.7,148.9,136.8$, 127.2, 126.9, 126.6, 123.5, 109.5, 72.3, 55.4, 45.2, 37.6, 34.6, 33.8, 30.2, 29.6, 25.8, 22.1, 20.9, 20.8; IR (KBr) $v / \mathrm{cm}^{-1} 3508,2938,1425,1075,1017,859$; HRMS (FTMS + pESI) $\mathrm{m} / z$, calculated for $\mathrm{C}_{22} \mathrm{H}_{35} \mathrm{NO}_{2} \mathrm{H}[\mathrm{MH}]^{+}$: 346.2746, found: 346.2745 ; melting point: $104^{\circ} \mathrm{C}$.

Synthesis of 2-(tert-butyl)-6-((E)-(((1S,2S,5R)-2-hydroxy2-methyl-5-(prop-1-en-2-yl)cyclohexyl)imino)methyl)4-methylphenol (8b)

The procedure was identical to the synthesis of $\mathbf{7 a}$, starting from $103 \mathrm{mg}(0.30 \mathrm{mmol})$ of $\mathbf{5 b}$. Yield: $76 \mathrm{mg}$ (74\%) of a yellow viscous material.

$[\alpha]_{D}{ }^{25}+30.8^{\circ}\left(c\right.$ 1.478, $\left.\mathrm{CHCl}_{3}\right) ;{ }^{1} \mathrm{H}$ NMR $(400 \mathrm{MHz}$, $\left.\mathrm{CDCl}_{3}\right) \delta 7.00(\mathrm{~d}, 1 \mathrm{H}, J 2.2), 6.71(\mathrm{~d}, 1 \mathrm{H}, J 2.2), 4.80-4.73$ $(\mathrm{m}, 2 \mathrm{H}), 4.04(\mathrm{~d}, 1 \mathrm{H}, J 13.2), 3.81(\mathrm{~d}, 1 \mathrm{H}, J 13.2), 3.78-3.68$ $(\mathrm{m}, 1 \mathrm{H}), 2.65(\mathrm{t}, 1 \mathrm{H}, J 3.8), 2.24(\mathrm{~s}, 3 \mathrm{H}), 2.06(\mathrm{t}, 1 \mathrm{H}$, $J 10.4 \mathrm{~Hz}), 1.97-1.86(\mathrm{~m}, 1 \mathrm{H}), 1.67-1.53(\mathrm{~m}, 11 \mathrm{H}), 1.41$ (s, 9H), 1.30 (s, 3H); ${ }^{13} \mathrm{C}$ NMR (101 MHz, $\left.\mathrm{CDCl}_{3}\right) \delta 154.5$, 148.6, 136.7, 127.3, 127.1, 126.8, 123.1, 109.5, 71.6, 62.7, $61.2,51.1,37.8,34.8,34.6,29.9,29.6,28.7,26.9,26.1$, 21.2, 20.8; IR (KBr) $v / \mathrm{cm}^{-1} 3406,2951,1639,1436,1213$, 887, 767, 501; HRMS (FTMS + pESI) $\mathrm{m} / \mathrm{z}$, calculated for $\mathrm{C}_{22} \mathrm{H}_{35} \mathrm{NO}_{2} \mathrm{H}[\mathrm{MH}]^{+}:$346.2746, found: 346.2744 .

\section{Single crystal $\mathrm{X}$-ray diffraction studies}

Single crystal of 5a and 6a suitable for X-ray diffraction studies were grown by slow evaporation of the solvent from a concentrated DCM/hexane solution of the compounds. A Bruker D8 Venture dual source diffractometer equipped with a Photon 100 complementary metal-oxide-semiconductor (CMOS) detector was used to collect X-ray data for the structural analysis of the compounds. Data were collected using $\mathrm{Cu} \mathrm{K} \alpha$ (5a) and Mo $\mathrm{K} \alpha(\mathbf{6 a})$ radiation, and a combination of $\varphi$ and $\omega$ scans was carried out to obtain at least one unique data set. The crystal structures were solved using direct methods in the SHELXS program..$^{35}$ The final structures were refined using SHELXL, ${ }^{35}$ where the remaining atoms were located from difference Fourier synthesis in which anisotropic displacement parameters were applied to all non-hydrogen atoms, followed by fullmatrix least-squares refinement based on $\mathrm{F}^{2}$. All hydrogen atoms were placed in ideal positions and refined as riding atoms with relative isotropic displacement parameters. Additional structural information for $\mathbf{5 a}$ and $\mathbf{6 a}$ are provided in SI section.

\section{Supplementary Information}

Crystallographic data for the structures in this work (Table S1) were deposited in the Cambridge Crystallographic Data Centre as supplementary publication number CCDC 1585565 and 1585568. Copies of the data can be obtained free of charge at http://www.ccdc. cam.ac.uk/conts/retrieving.html or from the Cambridge Crystallographic Data Centre, CCDC, 12 Union Road, Cambridge CB2 1EZ, UK; fax: +44 1223 336033. E-mail: deposit@ccdc.cam.ac.uk.

The full characterization spectra of new compounds are available free of charge at http://jbcs.sbq.org.br as a PDF file.

\section{Acknowledgments}

The authors thank E. A. Cechinatto for the HRMS analysis, Prof B. Tirloni for the XRD analysis and CNPq, FAPERGS and PROPESQ/UFRGS for financial support and fellowships to RSF and EOB.

\section{References}

1. Samir, M.; Alami, I. E.; Amin, M.; Amrani, E.; AgbossouNiedercorn, F.; Suisse, I.; Mortreux, A.; Chem. Eur. J. 2015, 21, 1398 .

2. United States Department of Agriculture (USDA); Citrus: World Market and Trades, Foreign Agricultural Services, Washington, USA, 2019. Avaliable at https://apps.fas.usda.gov/psdonline/ circulars/citrus.pdf accessed on August 13, 2019.

3. World Health Organization (WHO); Some Naturally Occurring Substances: Food Items and Constituents, Heterocyclic Aromatic Amines and Mycotoxins; IARC: Lyon, 1993, 56, 135.

4. Ciriminna, R.; Lomeli-Rodriguez, M.; Demma Carà, P.; LopezSanchez, J. A.; Pagliaro, M.; Chem. Commun. 2014, 50, 15288.

5. Sanseverino, A. M.; Silva, F. M.; Jones, J.; Mattos, M. C. S.; J. Braz. Chem. Soc. 2000, 11, 381.

6. Mattos, M. C. S.; Bernini, R. B.; J. Braz. Chem. Soc. 2007, 18, 1068.

7. Bachi, M. D.; Korshin, E. E.; Hoos, R.; Szpilman, A. M.; Ploypradith, P.; Xie, S.; Shapiro, T. A.; Posner, G. H.; J. Med. Chem. 2003, 46, 2516.

8. Hamann, L. G.; Meyer, J. H.; Ruppar, D. A.; Marschke, K. B.; Lopez, F. J.; Allegretto, E. A.; Karanewsky, D. S.; Bioorganic Med. Chem. Lett. 2005, 15, 1463.

9. Ferrarini, S. R.; Graebin, C. S.; Limberger, J.; Canto, R. F.; Dias, D. O.; Rosa, R. G.; Madeira, M. F.; Eifler-Lima, V. L.; Mem. Inst. Oswaldo Cruz 2008, 103, 773.

10. Graebin, C. S.; Madeira, M. F.; Yokoyama-Yasunaka, J. K. U.; Miguel, D. C.; Uliana, S. R. B.; Benitez, D.; Cerecetto, H.; 
González, M.; Rosa, R. G.; Eifler-Lima, V. L.; Eur. J. Med. Chem. 2010, 45, 1524.

11. Vandresen, F.; Falzirolli, H.; Almeida Batista, S. A.; SilvaGiardini, A. P. B.; Oliveira, D. N.; Catharino, R. R.; Ruiz, A. L. T. G.; Carvalho, J. E.; Foglio, M. A.; Silva, C. C.; Eur. J. Med. Chem. 2014, 79, 110.

12. Figueiredo, I. M.; Santos, L. V.; Costa, W. F.; Carvalho, J. E.; Silva, C. C.; Sacoman, J. L.; Kohnb, L. K.; Sarragiotto, M. H.; J. Braz. Chem. Soc. 2006, 17, 954.

13. Almeida Batista, S. A.; Vandresen, F.; Falzirolli, H.; Britta, E.; Oliveira, D. N.; Catharino, R. R.; Gonçalves, M. A.; Ramalho, T. C.; Porta, F. A.; Nakamura, C. V.; Silva, C. C.; J. Mol. Struct. 2019, 1179, 252.

14. Wender, P. A.; Zhang, L.; Org. Lett. 2000, 2, 2323.

15. Srikrishna, A.; Dethe, D. H.; Org. Lett. 2003, 5, 2295.

16. Mehta, G.; Shinde, H. M.; Tetrahedron Lett. 2003, 44, 7049.

17. Mattos, M. C. S.; Elias, S. M.; J. Braz. Chem. Soc. 1995, 6, 377.

18. Pisoni, D. S.; Silva, D. B.; Schenato, R. A.; Ceschi, M. A.; J. Braz. Chem. Soc. 2004, 15, 652.

19. Lahuerta, P.; Moreno, E.; Monge, A.; Muller, G.; Sanau, M.; Pe, J.; Eur. J. Inorg. Chem. 2000, 2, 2481.

20. Muller, G.; Sainz, D.; J. Organomet. Chem. 1995, 495, 103.

21. Steiner, D.; Sethofer, S. G.; Goralski, C. T.; Singaram, B.; Tetrahedron: Asymmetry 2002, 13, 1477.

22. Watts, C. C.; Thoniyot, P.; Hirayama, L. C.; Romano, T.; Singaram, B.; Tetrahedron: Asymmetry 2005, 16, 1829.

23. Rachwalski, M.; Tetrahedron Asymmetry 2014, 25, 219.

24. Wujkowska, Z.; Jarzyński, S.; Pieczonka, A. M.; Leśniak, S.; Rachwalski, M.; Tetrahedron: Asymmetry 2016, 27, 1238.
25. Le, T. M.; Csámpai, A.; Fülöp, F.; Szakonyi, Z.; Chem. - Eur. J. 2018, 51, 13607.

26. Ibn El Alami, M. S.; El Amrani, M. A.; Dahdouh, A.; Roussel, P.; Suisse, I.; Mortreux, A.; Chirality 2012, 24, 675.

27. Watts, C. C.; Thoniyot, P.; Cappuccio, F.; Verhagen, J.; Gallagher, B.; Singaram, B.; Tetrahedron: Asymmetry 2006, 17, 1301

28. Roszkowski, P.; Maurin, J. K.; Czarnocki, Z.; Tetrahedron: Asymmetry 2013, 24, 643.

29. Kokina, T. E.; Glinskaya, L. A.; Klevtsova, R. F.; Boguslavskii, E. G.; Sheludyakova, L. A.; Bizyaev, S. N.; Tkachev, A. V.; Larionov, S. V.; Russ. J. Coord. Chem. 2009, 35, 200.

30. Kokina, T. E.; Tkachev, A. V.; Myachina, L. I.; Bizyaev, S. N.; Sheludyakova, L. A.; Glinskaya, L. A.; Korol'kov, I. V.; Boguslavskii, E. G.; Larionov, S. V.; Russ. J. Gen. Chem. 2013, 83, 336.

31. Rudler, H.; Gregorio, J. R.; Denise, B.; Bregeault, J.-M.; Deloffre, L.; J. Mol. Catal. A: Chem. 1998, 133, 255.

32. Cimarelli, C.; Fratoni, D.; Palmieri, G.; Tetrahedron: Asymmetry 2009, 20, 2234.

33. Royals, E. E.; Leffingwell, J. C.; J. Org. Chem. 1966, 31, 1937.

34. Steiner, D.; Ivison, L.; Goralski, C. T.; Appell, R. B.; Gojkovic, J. R.; Singaram, B.; Tetrahedron: Asymmetry 2002, 13, 2359. 35. Sheldrick, G. M.; Acta Cryst. 2008, A64, 112.

Submitted: January 8, 2019 Published online: August 23, 2019 